\title{
Storm Tilo over Europe in November 2007: storm surge and impacts on societal and energy infrastructure
}

\author{
Anthony James Kettle \\ Department of Geography, Maynooth University, Maynooth, Co. Kildare, Ireland \\ Correspondence: Anthony James Kettle (ake3358@gmail.com)
}

Received: 27 May 2019 - Revised: 27 August 2019 - Accepted: 12 September 2019 - Published: 4 November 2019

\begin{abstract}
Storm Tilo on 8-9 November 2007 ranks among the serious winter storms in northern Europe over the past 30 years. Its low pressure centre passed across the northern North Sea, and this led to a cold air outbreak in northwest Europe. Strong north winds across the North Sea contributed to a high storm surge that was serious for coastal regions in eastern England, the Netherlands and Germany. Storm winds and unusually high waves caused shipping accidents and damage to some offshore energy infrastructure. This report presents an outline of the met-ocean conditions and a short overview of storm impacts on societal and energy infrastructure. The progress of the storm surge around the North Sea is analysed using data from the national tide gauge networks. A spectral analysis of the water level data is used to isolate the long period storm surge and short period oscillations (i.e., $<4.8 \mathrm{~h}$ ) from the tidal signal. The calculated skew surge is compared with literature reports for this storm and also with another serious North Sea storm from 31 October-1 November 2006 (Storm Britta). The short period oscillations are compared with the platform and shipping incident reports for the $2 \mathrm{~d}$ storm period. The results support previous reports of unusual wave and water level dynamics during some severe regional winter storms.
\end{abstract}

\section{Introduction}

Winter storms in northern Europe are a potentially serious hazard that can interrupt and damage societal and energy infrastructure. Northwest Europe has been impacted by a higher frequency of damaging winter wind storms starting about the late 1980s that have resulted in high insurance losses (Berz, 2005). While some of this may be due to the increased construction of infrastructure in exposed locations, there is evidence that the storms have also become larger and more intense. One special type of winter storm, typically passing on an eastward trajectory across the northern North Sea is serious for coastal and offshore infrastructure in Europe from its associated storm surge and wave field. Although not typically ranked with the highest insurance losses, this type of maritime storm is serious for energy infrastructure around the North Sea, including offshore petroleum platforms, wind energy infrastructure, and coastal power plants.

Coastal flooding during storms represents a potentially serious hazard for energy infrastructure, and this issue has been highlighted by Paskal (2009) and Cruz and Krausmann (2013) especially with scenarios of future sea level rise. Paskal (2009) presents an overview of the threat of storm surge flooding of coastal nuclear power stations, and there have been two notable cases in Europe. On 13 December 1981 the nuclear power plant at Hinkley Point in the Bristol Channel of the southwest England was shut down as the result of coastal flooding during an intense storm whose low pressure centre passed across southern Wales on an eastward track (Flather et al., 1982; Kirby, 2010). On 27 December 1999 the Le Blayais nuclear power station in the Gironde estuary of western France was forced to shut down as the result of seawater flooding caused by a breach of dyke defences by the combined action of a sea surge and high waves during an intense storm (Salomon, 2002; de Fraguier, 2010). For both events but particularly at Le Blayais, the action of the wave field on the sea walls may have been important for the ultimate flooding event. However, a complete geophysical analysis of the events has been limited by the lack of water level and wave data, in part due to failures of the tide gauge recorders. These accidents highlight that extreme coastal flood levels were not fully appreciated in the initial design criteria of the power stations in the 1960s and 1970s. 
Cases of wintertime coastal flooding like this are caused by storm surges acting on top of high tides, but there is also an important impact of the wind-wave field and possibly other dynamic features that are poorly understood. During a storm surge, water is pushed shoreward under the surface stress of strong winds, with an additional increase of water level in response to the lower atmospheric pressure that typically characterizes winter storm events (i.e., the inverted barometer effect). During hurricanes and cyclones at low latitudes, maximum surge levels can reach $9 \mathrm{~m}$ (Pugh, 1987), and for Hurricane Katrina in the northern Gulf of Mexico water levels of $7.5 \mathrm{~m}$ were recorded (Muir-Wood and Grossi, 2008). For North Sea storm surges, the local effect of storm winds and atmospheric pressure is augmented by a travelling storm surge wave that enters the North Sea north of Scotland and moves counter-clockwise around the basin as a coastallytrapped wave with a similar speed as the semi-diurnal tide. This can result in water levels reaching $>4 \mathrm{~m}$ above the average high tide level in the southern North Sea for the worst winter storm surge events (Ishiguro, 1981). Waves on different time and spatial scales have an important role in augmenting coastal erosion and infrastructure damage during the storm flooding events. Harbour seiches - oscillations in semi-enclosed basins with time scales of minutes to hours are a widely known phenomenon around the world including the North Sea (Pugh, 1987). Mostly, the amplitudes of harbour seiches tend to be small relative to the tide and storm surge water levels. However, under certain resonance conditions, associated with basin geometry and the speed of travelling weather disturbances, these can be greatly increased in amplitude, up to 5-6 $\mathrm{m}$ for the highest known cases in the Mediterranean Sea. These special cases have the height and frequency characteristics of tsunamis and have been identified as "meteotsunamis" (Monserrat et al., 2006; Pattiaratchi and Wijeratne, 2015). The phenomenon is also known in the North Sea but has mostly been a second order effect that is smaller than the tidal amplitude (but see also Pugh and Woodworth, 2014). De Jong and Battjes (2004) highlighted the case of seiches in Rotterdam Harbour during storms, an important issue because of the potential threat to ship navigation and the storm surge barrier. Kettle (2018) showed that similar harbour seiches excited during Storm Britta in 2006 were a widespread phenomenon in North Sea coastal areas with some coherence among regional stations. The anomalous surge measured at Delfzijl during Storm Britta on 1 November 2006 may belong to this type of phenomena, but little is known about it other than the fact that it could not be explained by existing surge models (RWS, 2006a, b, 2007a), and it may be due to physical processes with temporal and spatial characteristics that are smaller than present storm surge model resolutions (Stoffelen, 2014).

Infragravity waves with periods of $25-130 \mathrm{~s}$ remain a poorly understood phenomenon but may potentially be an important factor for coastal erosion and offshore infrastructure damage. High amplitude wave groups with long peri- ods approaching this range have been linked with damage to the FINO1 offshore wind energy research platform in the German Bight (Hessner and Reichert, 2007; Neumann and Nolopp, 2007; Rosenthal et al., 2011; Pleskachevsky et al., 2012) and with certain ship accidents (e.g., KNRM, 2007). Terlouw (2013) has invoked infragravity waves to explain deeply-penetrating erosion damage in narrow coastal sections of Ameland, one of the West Frisian Islands, during Storm Britta in 2006. Spencer et al. (2015) surveyed similar patterns of coastal damage on the North Norfolk coast after Storm Xaver in December 2013 and indicated travelling oceanographic features in coastal tide gauges and offshore wave recorders. The underlying physical mechanisms that give rise to these types of wave events are unclear. The presentation of Rosenthal et al. (2008) shows the model results of a ship-type wake pattern in the context of Storm Britta but with much larger dimensions that might result from a travelling low pressure centre. In an investigation of the New Year's Day storm of 1995, Rosenthal et al. (2011) highlights that two notable ship accidents in the northern and southern parts of the North Sea occurred under the same convective cloud band, and there is a possibility of a concentration of wave energy along atmospheric convergence lines in the flow direction of certain offshore storms. Another hypothesis relates to a resonant amplification of travelling wave groups from atmospheric gust structures moving at nearly the same speed during certain winter storms with open cloud cell convective structures (Rosenthal et al., 2011; Pleskachevsky et al., 2012).

Storm Tilo struck northwest Europe on 8-9 November 2007 and belongs in the same category of severity as the New Year's Day storm of 1995, Storm Britta (2006) and Storm Xaver (2013) as an important maritime storm with an unusual sea state that caused damage in unexpected offshore accidents (Rosenthal et al., 2011). Similar to other serious North Sea storms, Tilo passed on a northern track eastward across the northern North Sea, and it had a cold air outbreak behind the travelling low pressure centre (Lefebvre, 2008). In the unstable atmospheric conditions over the North Sea, a southward moving array of open-centre atmospheric convection cells formed, a condition that has been linked with large wave events during previous storms (Rosenthal et al., 2011; Pleskachevsky et al., 2012). Storm Tilo affected offshore energy infrastructure in several ways. Production at several Norwegian North Sea petroleum platforms was shut down as workers were evacuated in advance of the event (Upstream, 2007a, b) as part of that country's safety procedures for extreme maritime storms (Magnusson, 2008). Winds at the Norwegian platform of Ekofisk reached over $20 \mathrm{~m} \mathrm{~s}^{-1}$, and a rogue wave was documented early on 9 November 2007 before the maximum winds (Magnusson and Donelan, 2013; Donelan and Magnusson, 2017). Within the UK economic zone of the North Sea, the newly constructed Buzzard Platform was damaged at a high level of construction on 9 November 2007, resulting in production 


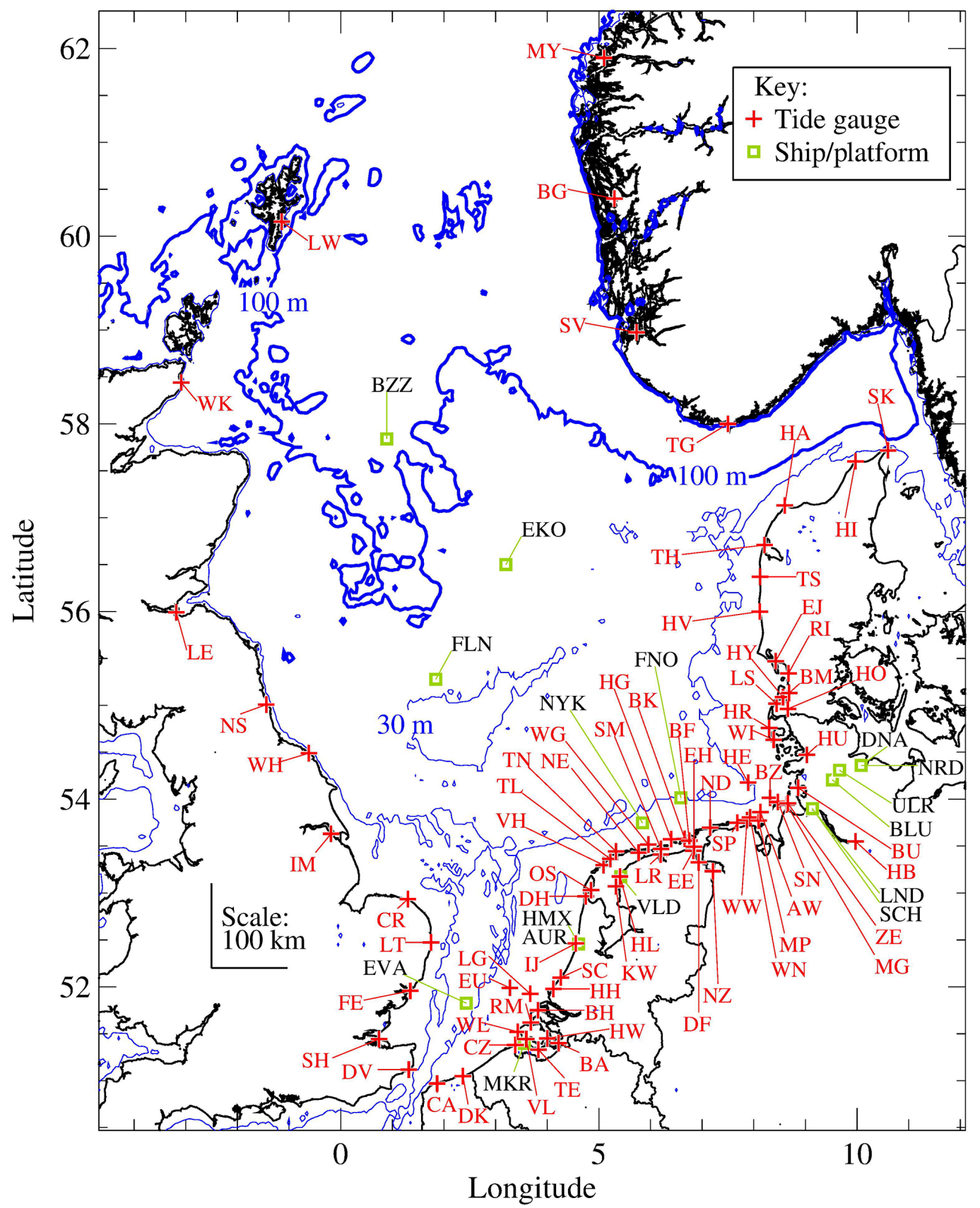

Figure 1. Map of tide gauge stations and shipping/platform incidents during Storm Tilo on 8-9 November 2007.

operations to be shut down (Upstream, 2007c, d; Lloyd's Casualty Week, 2007). For the wind energy industry, the storm caused several significant events. The offshore wind energy research platform FINO1 was damaged by waves at $15 \mathrm{~m}$ above sea level in an incident similar to Storm Britta on 1 November 2006 (Outzen et al., 2008). There were several onshore wind farm incidents in Scotland (Caithness Windfarms, 2018). The storm was associated with a serious coastal storm surge that caused minor flooding in eastern England
(Metoffice, 2011). In the Netherlands, it led to the first-ever closure of the storm surge barrier protecting the port of Rotterdam, and heightened dyke monitoring along the entire coast (RWS, 2007b). Along certain sections of the German coast, there were dune collapses (Heyken, 2007). There were also a number of ship and platform incidents across the North Sea where the winds or sea state were reported to have had an important role. The Supplement gives a list of the sources reviewed for this report, together with a set of thematic ta- 
bles with more information on the different met-ocean aspects and societal impacts of the storm.

\section{Methods}

The water level data from 76 tide gauges around the North Sea (Fig. 1) were analysed to characterize their storm surge component and short period oscillations. The tide gauge data originate from the national tide gauge networks of the UK, France, the Netherlands, Germany, Denmark, and Norway. Data quality was assessed visually, and for the UK stations, quality assessment was facilitated by the annual tide gauge report from the government authority (Natural Environment Research Council, 2007). The water level data sets had a time resolution of $10 \mathrm{~min}$, except for the UK (15 min), Germany (1 $\mathrm{min})$, and the two GESLA stations for France (60 min). The $1 \mathrm{~min}$ data for the German tide gauge stations were averaged onto a $10 \mathrm{~min}$ grid to facilitate subsequent processing. Further information about the tide gauges is given in Table S1 in the Supplement. The spectral components of the $14 \mathrm{~d}$ time series intervals across the storm period (1-14 November, inclusive) were calculated using a discrete Fourier transform (Stull, 1988). Spectral graphs were produced to identify the dominant tidal and storm surge periods (see Fig. 2). The spectral information was used to reconstruct three component time series with different frequency bands corresponding the storm surge (with periods greater than $1.2 \mathrm{~d}$ ), tides (with periods between 0.2 and $1.2 \mathrm{~d}$ ), and short period oscillations (with periods less than $0.2 \mathrm{~d}$ ). The tides in the North Sea have a dominant semi-diurnal component and a smaller diurnal component. The division of $1.2 \mathrm{~d}$ between the tidal band and the storm surge band was chosen on the basis of a minimum inflection at this period shown in many spectral graphs (see Fig. 2). The division of $0.2 \mathrm{~d}$ (or $4.8 \mathrm{~h}$ ) between tidal and short period oscillations was chosen empirically so that for most water level stations the reconstructed time series would have a smooth profile with two semi-diurnal peaks per day (see also Kettle, 2018). Other investigations of meteotsunamis have used similar filtering techniques to isolate the meteotsunami signal from the tide, and different frequency cutoff thresholds have been used corresponding to periods that vary between 2 and $6 \mathrm{~h}$ (Monserrat et al., 2006; Pattiaratchi and Wijeratne, 2015).

The statistics of the short period time series component were calculated to characterize periods and amplitudes of the oscillation structures for the $2 \mathrm{~d}$ storm period (8-9 November). This included a count of the number of complete zero crossing oscillations present, the maximum (crest height) and minimum (trough depth) of each oscillation, and the troughto-crest oscillation height. This was conducted separately for the down-crossing and up-crossing oscillations. Following observations of a ringing dissipation effect in certain tide gauge stations during Storm Britta (Kettle, 2018), an analysis was conducted to assess how the highest trough-to-peak

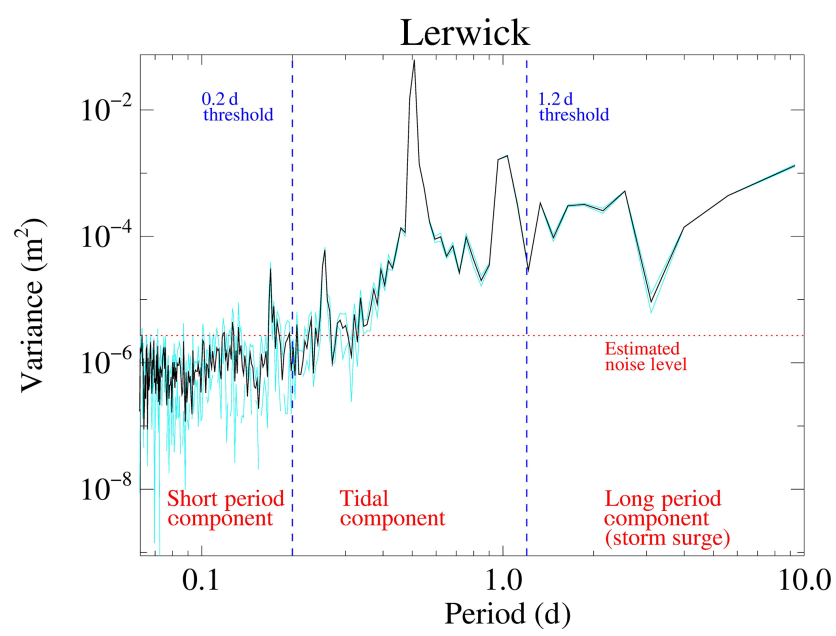

Figure 2. Spectrum of the water level time series from Lerwick, UK for 1-14 November 2007. The original 15 min time series was subsampled to give three data sets of $45 \mathrm{~min}$ resolution from which the spectral mean and standard deviation uncertainty could be calculated, as shown. The noise level was estimated based on the standard deviation of the first difference of the original time series.

oscillation for each tide gauge station during Storm Tilo decayed during successive oscillations.

A data base of 16 shipping and offshore platform incidents was compiled from media, trade, and scientific reports. Lloyd's Casualty Week (2007) was the most important source of this information, and most of the accident reports could be corroborated in different sources. The incidents were grouped into different categories according to the reported nature of the accident: ship collisions or groundings, containers or deck cargo washed overboard, engine problems or power blackout, and injuries or man overboard. Most of these offshore incident reports mention bad weather conditions as a contributing factor, and one case ("NYK Antares") specifically attributes containers lost overboard to a single wave event. Information on the incidents is summarized in Table S2 with a list of sources. Most of the reports give fairly precise information on the location and time of the accidents, and it is possible to compare them with the short period oscillation features observed in the water level data. Although some of the infrastructure events may have been caused by large infragravity waves whose time duration would be too short to register on tide gauges (e.g., KNRM, 2007), the impact of these waves on nearby coasts and harbours may have excited transient harbour seiches with periods on the order of 10 s of minutes, which is within the measurement capability of water level recorders.

\section{Results}

The main results of the spectral analysis and time series reconstructions are shown in the four panels of Fig. 3. The first 


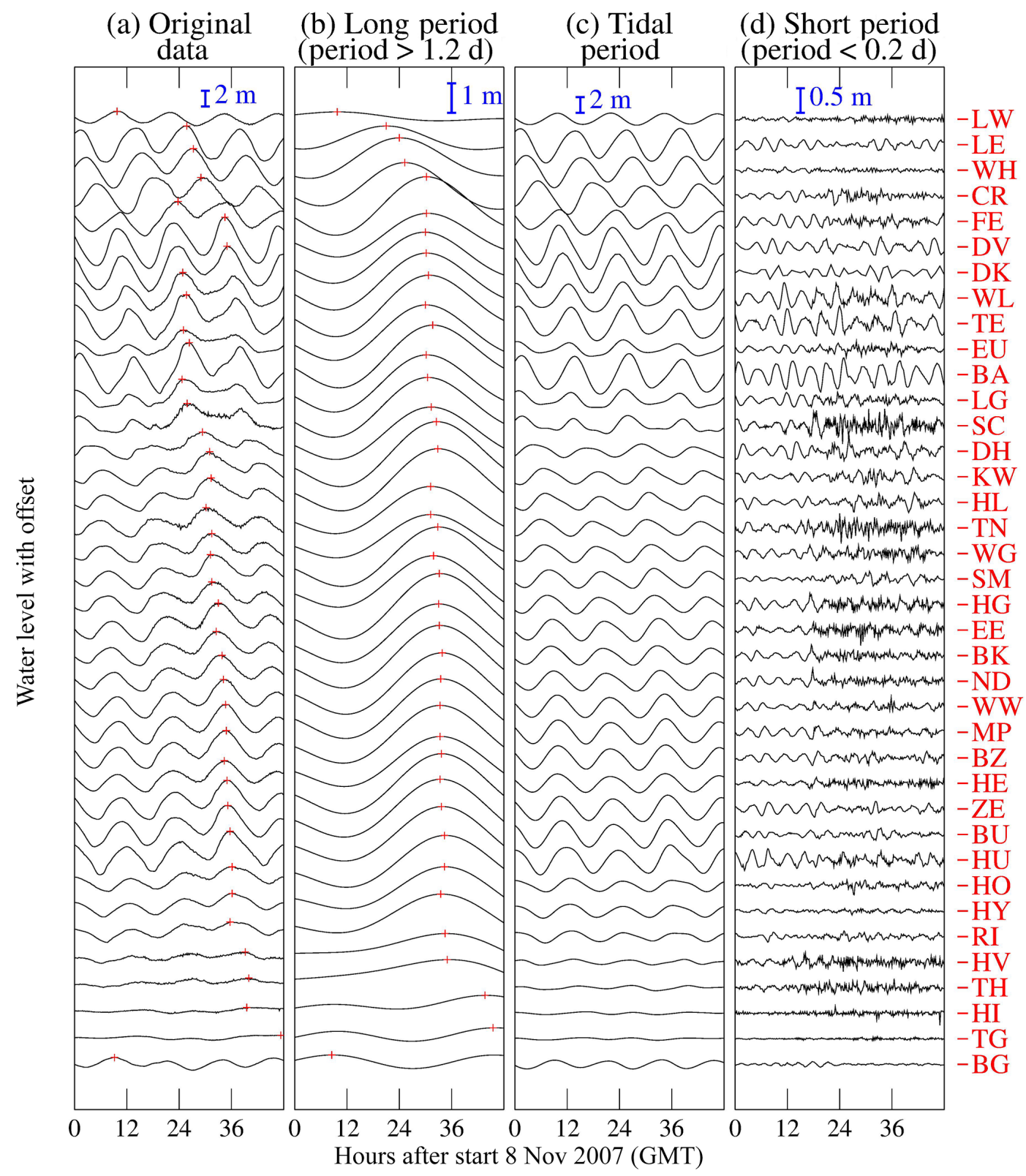

Figure 3. (a) Original tide gauge time series for the 2 d interval of Storm Tilo 8-9 November 2007 and reconstructions for the (b) long period component (periods $>1.2 \mathrm{~d}$; storm surge), (c) intermediate period component (periods in the range 0.2-1.2 d; tide), and (d) short period component (periods $<0.2 \mathrm{~d}$; harbour seiche). The plot shows a subset of time series data from 38 stations, and the full data set of 76 stations used in this project is shown in the Supplement.

panel (Fig. 3a) shows the original water level time series data for the storm period 8-9 November 2007. The time series are plotted with a vertical offset and arranged counter-clockwise around the North Sea starting with Lerwick north of Scotland and ending with Maløy in western Norway. The main feature of this series is the semi-diurnal tide, and locations in the southern North Sea show higher tidal ranges than other locations in northern Denmark and western Norway. Some of the stations show short period features that appears as a noisy fluctuation on the dominant tidal features. The maximum wa- ter levels for these series are shown by red crosses, and these highlight the progression of the tide and storm surge peaks around the North Sea.

The time series reconstructions from the spectral analysis clarify the different time scale components of the original time series, and these are shown in the panels of Fig. 3b-d. Figure $3 \mathrm{~b}$ shows the storm surge peak as it travels around the North Sea from Scotland, and its amplitude was highest in the southern North Sea. Figure 3c shows the travelling peaks in the tidal frequency band, highlighting the semi- 


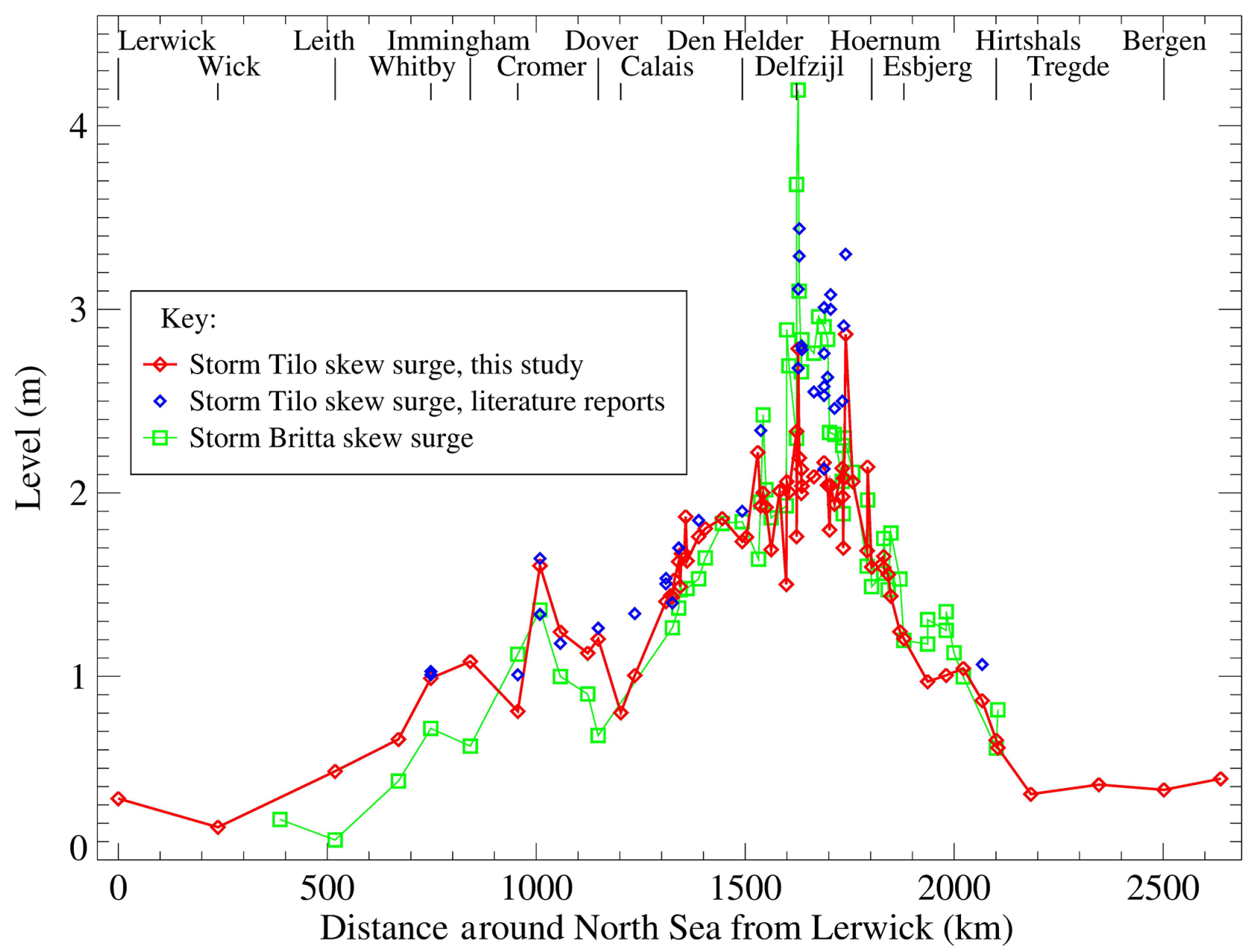

Figure 4. Calculated skew surge for Storm Tilo on 8-9 November 2007 with literature reports. The skew surge for Storm Britta on 31 October-1 November 2006 from Kettle (2018) has been shown for comparison.

diurnal component. Figure 3d shows the short period components from the tide gauges. For the short period component, there are six cases with the trough-to-peak oscillation heights exceeding $60 \mathrm{~cm}$, and the highest oscillation height at Nieuwe Statenzijl exceeded $90 \mathrm{~cm}$. Even though all the tide gauges have been processed with the same spectral analysis routines, there is a qualitative difference in the short period reconstructions with some clusters of stations exhibiting features of high frequency noise and others showing longer period wave-like features. Among some of the stations showing longer period oscillations, there are instances of temporal offsets that may be due to shallow water wave propagation or be linked with the field of atmospheric convection cells moving over the North Sea.

The height of the measured water level above the expected high tide prediction (i.e., skew surge; Williams et al., 2016) is an important parameter to assess the impact of storm surge coastal flooding. For this study, the height of the maximum measured water level (Fig. 3a) minus the median of the high tide peaks for period of the analysis of 1-14 November 2007 is shown for different locations around the North Sea in Fig. 4. For comparison, literature reports (Table S3) of the skew surge are also plotted, along with the skew surge analysis for the Storm Britta in 2006 from Kettle (2018; see Table S4). Figure 4 highlights how the skew surge reached above $2 \mathrm{~m}$ above the average high tide level for many stations in the northern Netherlands and the German Bight. For most stations along the coast of the UK and the southern Netherlands, Storm Tilo had a slightly higher skew surge than Storm Britta. For stations in the northern Netherlands and the German North Sea coast, the skew surge of Storm Britta was generally higher. The anomalous water level event recorded at Delfzijl during Storm Britta was noted in several national authority investigations (RWS, 2006a, b, 2007a), and Fig. 4 shows that it was higher than what was measured during Storm Tilo.

The relationship among the water level features at different time scales during Storm Tilo is shown in Fig. 5 along with 


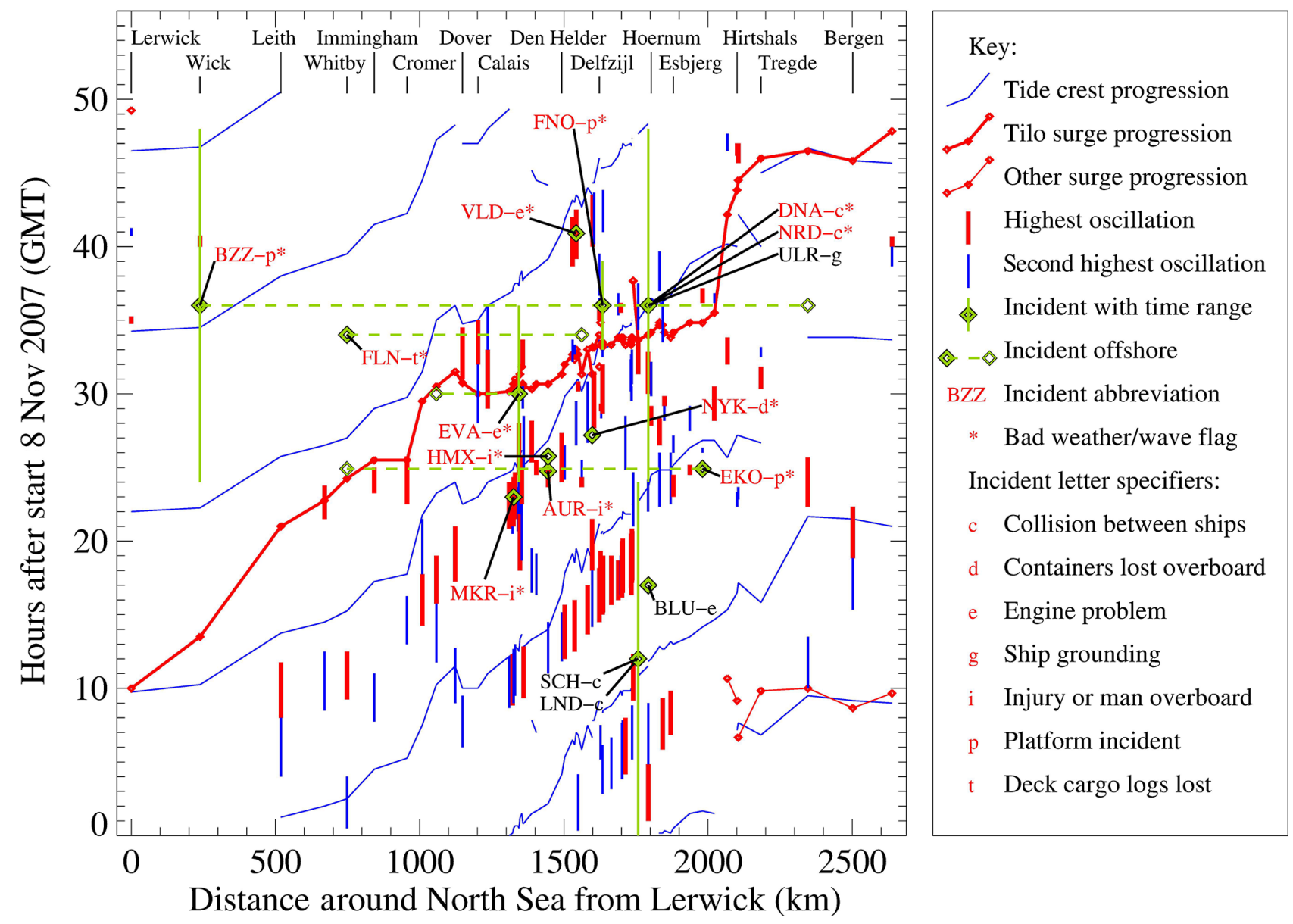

Figure 5. Relation between time and coastline distance around the North Sea during Storm Tilo on 8-9 November 2007 for the semi-diurnal tides, storm surge peak, highest two trough-to-peak heights of the down-crossing short period oscillations, and shipping/platform incidents.

the ship and offshore platform events. The diagram shows the data plotted on axes of time (hours after the start of 8 November 2007) versus counter-clockwise coastal distance around the North Sea starting from Lerwick in the UK. Because the tides and storm surge travel along the coast, Fig. 5 is a simplifying diagnostic that permits the representation of the multidimensional dynamics of the system (i.e., latitude, longitude, and time) on a two-dimensional graph. Four data sets are plotted for the $48 \mathrm{~h}$ period: the progression of the tidal maxima, the main storm surge maximum associated with Storm Tilo, the first and second highest trough-to-crest ranges of the short period oscillations, and the 16 shipping/platform incidents. (Figs. S1 and S2 in the Supplement show the four data sets separated into two graphs to facilitate inspection). The progression of the semi-diurnal tide peaks are shown as diagonal blue lines on the plot, which have been constructed by linking together semi-diurnal tidal crests between successive stations within a certain time window. The progression of the surge peak for Storm Tilo is shown by the heavy red line in the plot, and these have been constructed in the same manner as the semidiurnal tidal lines. The spectral analysis of the full $14 \mathrm{~d}$ time series yielded several other propagating storm surge crests of lower amplitude, and two of these appear as thin red lines and diamonds at the corners of Fig. 5. The data set of offshore ship and platform events is plotted as green diamonds with vertical bars and horizontal tie-lines for reports with temporal or spatial ambiguity.

There is a fairly close association of the propagating storm surge crest and the semidiurnal tidal in Fig. 5. The semidiurnal tide propagates with an average speed of $\sim 14-17 \mathrm{~m} \mathrm{~s}^{-1}$, corresponding to a water depth of $\sim 20-30 \mathrm{~m}$ for a shallow water wave. The moving storm surge crest is associated mainly with one semi-diurnal tidal crest, but the surge maximum occurs after the tide along the coasts of the UK and the southern Netherlands, while for the German Bight the high tide and storm surge crest occur at nearly the same time. The first and second highest trough-to-peak oscillations occur mainly before the tidal high water times during the storm surge period. In many cases, the offshore incidents were associated with the first or second highest short period oscillations. Because the short period oscillations have amplitudes of tens of centimetres and periods on the order of tens of 
minutes to hours, they do not directly record the wave field that was identified as a contributing factor in several offshore incidents. On the other hand, they indicate where an analysis of wave data recordings might be targeted for insight into the offshore incidents. Different related oscillation height diagnostics can be used to characterize the extreme short period oscillations in this type of diagram. These are shown in Figs. S3 and S4. Figure S3 is similar to Fig. 5 but uses up-crossing oscillation to show the highest crest-to-trough height ranges, and there are some differences related to the fact that the oscillations sometimes have a pronounced asymmetrical shape. Figure S4 selects the two extreme oscillations based on the crest heights instead of the trough-to-crest full height range. There are some differences in the pattern of the most extreme oscillations among these diagrams compared with Fig. 5, but the overall trends are similar. Figure S5 focuses on the pairwise comparison of the offshore events and the highest trough-to-peak height ranges of the short period oscillations of the closest tide gauge station, and it suggests that there may be a close association between these data sets.

The technical literature recognizes that the extreme water level fluctuations associated with tsunamis and harbour seiches last for periods of hours to days, oscillating at particular frequencies before decaying out through frictional energy losses (Pugh, 1987; Murty, 1977; Pattiaratchi and Wijeratne, 2015). Many published time series recordings of the phenomena show approximately exponentially decreasing trends. Murty (1977, p. 243) quantifies the trend in terms of a "decay constant", which would correspond to the inverse of the e-folding time in his mathematical treatment, and Dean and Dalrymple (1991) give more information on the mathematical description of exponentially decaying long waves. For the North Sea tide gauge data for Storm Tilo, many cases were found where the highest oscillation was directly followed by the second highest oscillation (Fig. 5). This indicates that there may be a ringing effect initiated by an excitation mechanism possibly associated with the travelling atmospheric convection cells (De Jong and Battjes, 2004). An analysis of this effect was conducted using the summary statistics of the down-crossing oscillations for 8-9 November 2007. For the $2 \mathrm{~d}$ of data for each station, the oscillation with the highest trough-to-peak range was identified, and the information for all the successively decreasing oscillations was extracted. The extracted data series had at least two and up to eight oscillations (for the case of Delfzijl). The data were fitted with an exponential decay model to yield a median value for the e-folding decay times of $3.3 \mathrm{~h}$ (range of 0.4-45.1 h), which agrees with results from Storm Britta in Kettle (2018). Additional information on the time span and e-folding decay times of the short period oscillations at individual stations is shown in Figs. S6, S7 and Table S5.

\section{Conclusions}

Storm Tilo ranks among the more serious storms of the past 30 years (Larsén et al., 2017) for its threat to energy infrastructure, especially offshore. Offshore platforms for petroleum production and wind energy research were damaged during this storm by the wind and wave field. The analysis of dynamical features in the tide gauge records for a series of stations around the North Sea reveals the progression of the surge, tides, and short period oscillations. The amplitude of the skew surge at different sections around the coast is highlighted, and the highest skew surge was along the coasts of the Netherlands and Germany. The reconstructed short period $(<0.2 \mathrm{~d})$ elements of the water level record revealed an oscillation or ringing phenomena that exceeded $60 \mathrm{~cm}$ in trough-to-crest height for several stations. These oscillations have previously been identified with the harbour seiche phenomenon (Pugh, 1987), but they also fall within the range of defining characteristics of meteotsunamis (Monserrat et al., 2006; Pattiaratchi and Wijeratne, 2015; Maxial et al., 2019). For Storm Tilo, the trough-to-peak height of these features was smaller than range of the tides and storm surge at most North Sea stations, so that they were of second order importance for coastal flooding risk. On the other hand, storm flood levels during Storm Britta exceeded the numerical model predictions that encapsulate the understanding of storm surge dynamics (RWS, 2006a, b, 2007a), and certain reports indicate there may have been a high risk of coastal dyke breaches and flooding (Ulm et al., 2018). As well, the highest of the short period oscillations during Storm Tilo appeared to show correspondence in time and location with some of the reported infrastructure events. Together with instances of coastal dune collapse and accounts of wave-damage of offshore infrastructure, this may indicate an important role for wave-like features on intermediate time and space scales between wind waves and the semidiurnal tide.

Data availability. The water level data for this study was measured by the national tide gauge networks of the UK, France, the Netherlands, Germany, Denmark, and Norway. The data were downloaded from publicly accessible websites maintained by the national authorities, except for France (dataset obtained through the GESLA online archive) and Germany (datasets sent by Wilfried Wiechmann of the Federal Institute of Hydrology in Germany). Further information on the URL internet addresses is given in Table S1 of the Supplement.

Supplement. The supplement related to this article is available online at: https://doi.org/10.5194/adgeo-49-187-2019-supplement. 
Author contributions. AJK conducted the data analysis, wrote the manuscript, and made a poster presentation at the EGU General Assembly 2019, Vienna, Austria.

Competing interests. The author declares that they have no conflict of interest.

Special issue statement. This article is part of the special issue "European Geosciences Union General Assembly 2019, EGU Division Energy, Resources \& Environment (ERE)". It is a result of the EGU General Assembly 2019, Vienna, Austria, 7-12 April 2019.

Acknowledgements. The author gratefully acknowledges data from national tide gauge networks of the UK, Netherlands, Germany, Denmark, and Norway, and the GESLA archive for France. The tide gauge data for the UK, France, the Netherlands, and Norway was downloaded from Internet servers. For Germany, Wilfried Wiechmann of the Federal Institute of Hydrology of Germany kindly provided tide gauge data by email. For Denmark, part of the tide gauge data was downloaded from public websites, and Bjørn Steen Frederiksen of Kystdirektoratet indicated a website where other tide gauge data could be accessed. Antke Reemts of the German Search and Rescue Service and Edwin Granneman of the Netherlands Coastguard provided information on some of the offshore incidents during Storm Tilo. The author appreciated conversations on offshore storm issues with other EGU2019 attendees: Dirk Becker, Elizabeth Bradshaw, Lidia Gaslikova, Gregor Giebel (ERE Energy Meteorology convener), Daniela Maxial, Vinca Rosmorduc, Pal Schmitt, Len Shaffrey, Ina Teusch, and Marius Ulm. The comments of two anonymous referees improved the manuscript.

Review statement. This paper was edited by Gregor Giebel and reviewed by two anonymous referees.

\section{References}

Berz, G.: Windstorm and storm surges in Europe: loss trends and possible counter-actions from the viewpoint of an international reinsurer, Phil. Trans. R. Soc. A, 363, 1431-1440, https://doi.org/10.1098/rsta.2005.1577, 2005.

Caithness Windfarms: WIND TURBINE ACCIDENT AND INCIDENT COMPILATION, available at: http: //www.caithnesswindfarms.co.uk/fullaccidents.pdf, last access: 30 September 2018.

Cruz, A. M. and Krausmann, E.: Vulnerability of the oil and gas sector to climate change and extreme weather events, Clim. Change, 121, 41-53, 2013.

Dean, R. G. and Dalrymple, R. A.: Water wave mechanics for engineers and scientists, World Scientific, New Jersey, 1991.

De Fraguier, E.: Lessons learned from 1999 Blayais flood: Overview of EDF flood risk management plan, RIC 2010 External Flood and Extreme Precipitation Hazard Analysis for Nu- clear Plant Safety Session, presentation to U.S. NRC, Regulatory Information Conference (RIC) at the Bethesda North Marriott Hotel and Conference Center, 11 March 2010.

De Jong, M. P. C. and Battjes, J. A.: Low-frequency sea waves generated by atmospheric convection cells, J. Geophys. Res., 109, C01011, https://doi.org/10.1029/2003JC001931, 2004.

Donelan, M. A. and Magnusson, A.-K.: The making of the Andrea Wave and other rogues, Sci. Rep.-UK, 7, 44124, https://doi.org/10.1038/srep44124, 2017.

Flather, R. A., Draper, L., and Proctor, R.: Coastal flooding in the Bristol Channel and Severn Estuary on 13th December 1981, IOS Internal Document No. 162, May, 1982.

Hessner, K. and Reichert, K.: Sea surface elevation maps obtained with a nautical X-band radar - Examples from WaMoS II stations, 10th International Workshop on Wave Hindcasting and Forecasting and Coastal Hazard Symposium, North Shore, Oahu, Hawaii, 11-16 November 2007.

Heyken, H.: Schwere Sturmflut an niedersächsischer Nordseeküste - Dünenabbrüche auf den Inseln, NLWKN press release, available at: https://www.nlwkn.niedersachsen.de/startseite/aktuelles/ presse_und_offentlichkeitsarbeit/pressemitteilungen/-43218. html (last access: 15 October 2019), 9 November 2007.

Ishiguro, S.: Storm surge predictions by the quasi uniform stead wind/pressure field method, Institute of Ocean Sciences, Internal Document 102, Wormley, Surrey, England, 1981.

Kettle, A. J.: The North Sea surge of 31 October-1 November 2006 during Storm Britta, Adv. Geosci., 45, 273-279, https://doi.org/10.5194/adgeo-45-273-2018, 2018.

Kirby, R.: Hinkley Point sediment transport - potential impacts of new structures, British Energy Estuarine \& Marine Studies Technical Report Series, BEEMS TR 149, September 2010.

KNRM: Capsize and Survival, Report on lifeboat Anna Margaretha's capsizes November 1st 2006, Koninklijke Nederlandse Redding, Maatschappij, 16 May 2007.

Larsén, X. G., Du, J., Bolaños, R., and Larsen, S.: On the impact of wind on the development of the wave fields during storm Britta, Ocean Dynam., 67, 1407-1427, https://doi.org/10.1007/s10236017-1100-1, 2017.

Lefebvre, C.: Orkan TILO am 8. und 9. November 2007, DWD report, available at: https://www.dwd.de/DE/leistungen/ besondereereignisse/stuerme/20071108_orkan_tilo.pdf? blob $=$ publicationFile $\& v=4$ (last access: 15 October 2019), 1 January 2008.

Lloyd's Casualty Week: Lloyd's Casualty Week, Lloyd's of London Press, Colchester, Essex, UK, 23 November 2007.

Magnusson, A. K.: Forecasting extreme waves in practice, Proceedings of Rogue Waves 2008, Brest, France, 13-15 October 2008 , 23 pp., 2008.

Magnusson, A. K. and Donelan, M. A.: The Andrea wave. Characteristics of a measured North Sea rogue wave, J. Offshore Mech. Arct., 135, 1-10, https://doi.org/10.1115/1.4023800, 2013.

Maxial, D., Omira, R., Baptista, M. A., Rabinovich, A., and Viterbo, P.: Meteotsunamis in the instrumental records of the Iberian coast: Oceanic and atmospheric data analysis towards building a meteotsunami catalogue, EGU General Assembly, 21, EGU2019-9953, Vienna, Austria, April 2019.

Metoffice: Storm surge - November 2007, https://www.metoffice. gov.uk/about-us/who/how/case-studies/floods-2007 (last access: 21 September 2018), last update: 11 May 2011. 
Monserrat, S., Vilibić, I., and Rabinovich, A. B.: Meteotsunamis: atmospherically induced destructive ocean waves in the tsunami frequency band, Nat. Hazards Earth Syst. Sci., 6, 1035-1051, https://doi.org/10.5194/nhess-6-1035-2006, 2006.

Muir-Wood, R. and Grossi, P.: The catastrophe modelling response to Hurricane Katrina, in: Climate Extremes and Society, edited by: Diaz, H. F. and Murnane, R. J., Cambridge University Press, Cambridge, UK, 296-319, 2008.

Murty, T. S.: Seismic Sea Waves Tsunamis, Bulletin of the Fisheries Research Board of Canada, Bulletin 198, Ottawa, 1977.

Natural Environment Research Council: Annual Report for 2007 for the UK National Tide Gauge Network and Related Sea Level Science, National Tide and Sea Level Facility, NERC 100017897, available at: https://www.bodc.ac.uk/data/hosted_data_systems/ sea_level/uk_tide_gauge_network/reports/ (last access: 15 October 2019), 2007.

Neumann, T. and Nolopp, K.: Three years operation of far offshore measurements at FINO1, DEWI Magasin, 30, 42-46, 2007.

Outzen, O., Herklotz, K., Heinrich, H., and Lefebvre, C.: Extreme waves at FINO1 research platform caused by storm 'Tilo' on 9 November 2007, DEWI Magazin, 33, 17-23, 2008.

Paskal, C.: The security implications of climate change in the OSCE region, Organization for security and co-operation in $\mathrm{Eu}-$ rope, Chairmanship Conference, Bucharest, 5 October 2009, PC.NGO/10/09, 12 October 2009.

Pattiaratchi, C. B. and Wijeratne, E. M. S.: Are meteotsunamis an underrated hazard?, Phil. Trans. R. Soc. A, 373, 2140377 , https://doi.org/10.1098/rsta.2014.0377, 2015.

Pleskachevsky, A. L., Lehner, S., and Rosenthal, W.: Storm observations by remote sensing and influences of gustiness on ocean waves and on generation of rogue waves, Ocean Dynam., 62, 1335-1351, https://doi.org/10.1007/s10236-012-0567-z, 2012.

Pugh, D. T.: Tides, Surges and Mean Sea Level, John Wiley and Sons, Chichester, 1987.

Pugh, D. and Woodworth, P.: Sea-Level Science. Understanding Tides, Surges, Tsunamis and Mean Sea-Level Changes, Cambridge University Press, Cambridge, 2014.

Rosenthal, W., Lehner, S., Schulz-Stellenflet, J., and König, T.: Investigation of ship accidents using global ERS-2 and ENVISAT wave mode, The 2nd International Workshop on Advances in SAR Oceanography from ENVISAT and ERS Missions, 21-25 January 2008, available at: http://www.earth.esa. int/seasar2008/participants/232/pres_232_rosenthal.pdf (last access: 8 October 2019), 2008.

Rosenthal, W., Pleskachevsky, A. L., Lehner, S., and Brusch, S.: Observation and modeling of high individual ocean waves and wave groups caused by a variable wind field, 12th International Workshop on Wave Hindcasting and Forecasting, Kohala Coast, Hawai'i, HI, 2011.

RWS: Verslag van de stormvloed van 31 oktober en 1 november 2006 (SR84), Allerheiligenvloed, Ministerie van Verkeer en Waterstaat, Rijkswaterstaat, Stormvloedwaarschuwingsdienst/SVSD, "s-Gravenhage, November 2006a.
RWS: Evaluatie Allerheiligenvloed 2006. Analyse van de voorspelling van de hoogwaterstand voor Delfzijl, 38 pp., Den Haag, the Netherlands, 24 November 2006 b.

RWS: Allerheiligenvloed 2006. Achtergrondverslag van de stormvloed van 1 november 2006, Rijkswaterstaat Rijksinstituut voor Kust en Zee/RIKZ, Artoos Drukkerijen, Rijswijk, the Netherlands, 30 June 2007a.

RWS: Verslag van de Stormvloed van 9 november 2007 (SR88), Ministerie van Verkeer en Waterstaat, Direktoraat-Generaal Rijkswaterstaat Waterdienst, Stormvloedwaarschuwingsdienst/SVSD, Postbus 17, 8200 AA Lelystad, Lelystad, 45 pp., November 2007b.

Salomon, J.-N.: L'inondation dans la basse vallée de la Garonne et l'estuaire de la Gironde lors de la "tempête du siècle" (27-28 décembre 1999)/Flooding in the Garonne valley and the Gironde estuary caused by the "storm of the century" (27-28 December 1999), in: Géomorphologie: relief, processus, environnement, Avril-juin, 8, 127-134, https://doi.org/10.3406/morfo.2002.1134, 2002.

Spencer, T., Brooks, S. M., Evans, B. R., Tempest, J. A., and Möller, I.: Southern North Sea storm surge event of 5 December 2013: Water levels, waves and coastal impacts, Earth-Sci. Rev., 146, 120-145, https://doi.org/10.1016/j.earscirev.2015.04.002, 2015.

Stoffelen, A.: Modelling Surges, Cork eSurge Training, Cork, Ireland, 20-21 February 2014.

Stull, R. B.: An Introduction to Boundary Layer Meteorology, Kluwer Academic Publishers, Dordrecht, 1988.

Terlouw, A.: Predicting morphological storm impact on coastal dunes at Ameland, MSc thesis, University of Twente, Enschede, 2013.

Ulm, M., Arns, A., and Jensen, J.: Black swans and risk - assessing consequences of extreme events for the German Bight, 36th International Conference on Coastal Engineering 2018 - Coastal Protection and Risk, Baltimore, Maryland, USA, 30 July-3 August 2018.

Upstream: Storms force Ekofisk closures, contributor: Michael O'Neill, 9 November 2007a.

Upstream: Passing storm keeps platforms shut, contributor: Rob Watts, 9 November 2007b.

Upstream: Storm downs Nexen's Buzzard, contributor: Jonathan Davis, 9 November 2007c.

Upstream: Storm clips Buzzard's wings, contributor: Anthea Pitt, 12 November $2007 \mathrm{~d}$.

Williams, J., Horsburgh, K. J., Williams, J. A., and Proctor, R. N. F.: Tide and skew surge independence: New insights for flood risk, Geophys. Res. Lett., 43, 6410-6417, https://doi.org/10.1002/2016GL069522, 2016. 